\title{
Mandatory nature of criminal proceedings in the republic of Latvia: Current issues and controversies
}

\author{
Sandra Kaija \\ Rīga Stradinsš University, Faculty of Law, Riga, Latvia
}

\begin{abstract}
The Criminal Procedure Law (Section 6), as one of the basic principles of the criminal procedure, provides for the mandatory nature of criminal proceedings. It determines that the official who is authorised to perform criminal proceedings has an obligation within his or her competence to initiate criminal proceedings and to lead such proceedings to the fair regulation of criminal legal relations provided for in The Criminal Law in each case where the reason and grounds for initiating criminal proceedings have become known. This research focuses on issues that relate to the legal aspects of the mandatory nature of criminal proceedings, including the competence of the officials in initiating criminal proceedings; the role of the victim; the purpose of this basic principle. This paper examines the problematic aspects of the mandatory principle in criminal procedure in Latvia. In the end, key conclusions are summarized.
\end{abstract}

Key words: criminal proceedings, mandatory, principle.

\section{Introduction}

The aim of the paper is to research legal aspects of mandatory nature of criminal proceedings, to identify problematic issues, and to propose solutions to them. Materials and methods. The research uses grammatical, systemic and teleological (meaning and purpose) methods of interpretation of legal norms, as well as descriptive, analytical and deduction-induction research methods. By applying these methods, legal acts and opinions of law scientists were analysed, which was followed by drawing conclusions and drafting recommendations.

\section{Results and discussion}

The author or this paper will determine and analyse the overall characteristics of the mandatory nature of criminal proceedings and their legal regulation in the legislation of the Republic of Latvia.

The basic principles of the criminal proceedings in the capacity of the leading norms, which application is possible during the entire course of the criminal proceedings, determine the nature and structure of the procedural order. The basic principles of the criminal proceedings form an overall system, which includes such principles of the criminal proceedings as the mandatory nature of the criminal proceedings, etc. [1].

The principles of the criminal proceedings are legal because they as general and leading procedural norms are frequently mentioned in the Constitution of the Republic of Latvia. Being connected to the objectives of the criminal proceedings, these principles indirectly 
follow the implementation of objectives via a special norm of the legal proceedings. The principles of the criminal proceedings are all integrated into one particular system and they determine the constraints of the conclusion of objectives of the legal proceedings and are closely linked to the Criminal Law and Court Organization guidelines. Although each principle of the criminal proceedings expresses a completely independent norm of the legal proceedings, it should be acknowledged that there are close ties and practical connection amongst them. One cannot contradict another one. Each principle is connected to another principle directly or via other guidelines [2].

One of the basic principles of the criminal proceedings is the mandatory nature of the criminal proceedings, which is in accord with Article 6 of the Criminal Procedure Law (CPL henceforth), which says that "Within the scope of his/her competences, the official who has the power of attorney to conduct the criminal proceedings has the obligation to initiate the criminal proceedings and ensure they proceed to the fair conclusion of the criminal legal relationship that is envisaged by the Criminal Law in each case when the cause and justification for the initiation of the criminal proceedings become known" [3].

Article 1 of CPL includes references that let conclude what exactly the public expects as the final outcome of the process, which is the fair conclusion of the relation set by the criminal law. Therefore, justice can be considered as both the aim and means of the criminal proceedings. It is implausible to attain the fair aim using unfair means. To ensure the justice aspect of the conclusion, fair material and procedural norms are required as well as their fair application. Article 1 of CPL determines "the basic rule" - as part of the criminal proceedings, a fair outcome must be attained, including the fair conclusion of the criminal legal relation at the same time one must consider the restrictions on the unfair intrusion into the personal life [4].

The CPL aim is to determine the order of the criminal proceedings that will ensure the effective application of the CL norms and the fair regulation of the criminal legal relation without unfair intrusion into the a person's life, hence, it can be concluded that the most important objective of CPL is not to punish persons but to reach the fair regulation of the criminal legal relation, which is envisaged also by Article 6 of CPL "The mandatory principle of the criminal proceedings".

The inclusion of the relevant norms into the CPL section "The basic principles of the criminal proceedings" plays a significant and far-reaching role both for creation of legal norms of the criminal procedure and their legal application into real life. The legislator must realize that by announcing one position as the basic principle of the field, the legislator has not only engaged in a formal activity, but also has taken the responsibility to subordinate all other norms to this key guideline. These basic principles have been formed as a "frame", which must be completed. Specifically, the norms that are being created cannot contradict the implementation of ideas of the principles in real life under any circumstances. Therefore, for the system to be stable and sustainable, in the first place, it is important to focus on the quality of the legal regulation of the principles as well as on the fact that the meaning of the principles must be familiar to the officials working on their implementation. Although these officials must follow the specific regulation norms of the specific activity, it is also important to ensure that their work, passed decisions etc. are in accord with the basic principles. These officials must understand the special meaning and role of these norms in the overall system of criminal procedure norms. They must also comprehend the consequences when these principles are not observed. Breaching the principles of the criminal proceedings associate with serious consequences, specifically, Section 4 of Article 130 of CPL provides that the information that has been obtained by breaching the basic principles of the criminal proceedings is considered as absolutely prohibitive and cannot be used in the subsequent court hearings [5]. 
What follows from the above discussion is that the Latvian criminal proceedings acknowledge the so-called legality principle as oppose to the opportunity principle. To a certain extent, the expediency of the principle resonates with the proportionality principle, although occasionally these principles are not sufficiently distinguished. However, even though expediency and proportionality are the evaluative concepts and on occasion they overlap, there might also be situations when they are distinguishable because it is not always the case that something that is effective might simultaneously be proportionate, and vice versa. Similarly, it might be emphasized that the observance of the proportionality principle, when deciding on whether the criminal proceedings can be the case in a specific context or not, might be more related to the material legal norms, while the expediency principle on whether to initiate the criminal proceedings is linked to the procedural norms [6].

The mandatory nature principle of the criminal proceedings, therefore, is tightly connected to and can be analysed only in the connection to the principle of the public prosecution. The concept of "public prosecution" was already known at the KPK times, but its interpretation has changed since then. The public prosecution process can be defined as the process that has been initiated independently of the victim's wishes and public interests [7].

According to the author, the basic principle of the criminal proceedings is the mandatory principle of the criminal proceedings and it is one of the most significant basic principles, which emphasizes the duties of the officials to pass the decision on the initiation of the criminal proceedings. The reasons, grounds and order for the initiation of the criminal proceedings are determined in Section 30 of the CPL, which is why in what follows the author will further analyse the reasons and grounds of the initiation of the criminal proceedings.

The initiation of the criminal proceedings commences when the prosecution institution or the prosecuting authority receive information on that a) an offence has taken place, or b) on that there is a possibility that an offence might take place. Using such information, the official with the power of attorney to initiate the criminal proceedings who works for the prosecuting authorities, having identified the reasons and grounds as determined in CPL, decides whether indeed to initiate the criminal proceedings, while observing the CPL norms.

Having identified the grounds for the initiation of the criminal proceedings, it is possible to immediately initiate the criminal proceedings, thus allowing the prosecution to use all criminal procedure means in the context of a specific possible offence. In accord with Article 369 of CPL [8], the reasons for the initiation of the criminal proceedings might be feasible to divide into two categories:

1. The reason for the initiation of the criminal proceedings is the information submission to the prosecution office or the prosecuting authorities, which point to committing of a possible offence;

2. or it could also be obtaining of such information by the responsible authorities in pertinence to the applied procedure of the criminal proceedings.

The indicated information can be submitted:

1) as a submission by a person who has suffered as a result of a criminal offence;

2) by controlling and supervising institutions, in accordance with the procedures provided for in the laws and regulations governing the activities thereof;

3) by medical practitioners or institutions, as a report regarding traumas, illnesses, or cases of death the cause of which may be a criminal offence;

4) by non-governmental organisations, and authorities protecting the rights of children, as a submission regarding infringements upon the rights of minors the cause of which may be a criminal offence; 
5) any natural person or legal person, as information regarding possible criminal offences from which such person has not directly suffered;

6) as a submission by any person regarding a criminal offence committed by such person.

The reason for the initiation of criminal proceedings may not be anonymous information or information whose submitter refuses to disclose the source of the information.

In turn, information can be obtained by the prosecution institution, prosecution authorities or court as a result of criminal procedural activities in the following cases:

1) directly determining a criminal offence at the time of the committing thereof, and discontinuing such offence;

2) directly determining clear consequences of a criminal offence;

3) performing criminal proceedings regarding another criminal offence;

4) performing other functions specified in laws: examinations, an investigative action, etc.

Upon obtaining or receiving information, there might emerge different situations.

1) In case there is a real chance that the offence has occurred or if the information is possible to check only using means and methods of the criminal proceedings (Article 370 of CPL), then the decision must be made to initiate the proceedings.

2) In case this information contains information about the violation of law, for which detection the use of means and methods of the criminal proceedings is not necessary (Section III of Article 373 of CPL), then it is forwarded for verification to the competent authority.

3) In case the official, who has received the power of attorney consistently with the procedure, determines that there is no justification for the initiation of the criminal proceedings (Section I of Article 373 of CPL), then this official either passes the decision to reject the initiation of the criminal proceedings or can pass the decision in the format of a resolution and in this case the person who has submitted the information about the possibility of an offence occurrence should be informed about this resolution, the exceptional cases being medical practioners and institutions.

Having received or obtained information, which points to the possible commitment of an offence, it is essential to pass a decision on whether this information offers the legal grounds for the initiation of the criminal proceedings. In this case two factors must be considered: 1) the criminal proceedings are initiated for the good of the public irrespective of the victim's wishes and 2) the criminal proceedings are initiated only when the victim's complaint has been received.

Justification for the category of the specific procedure type in case of a specific offence represents an especially important factor because it determines to a significant extent the outcome of such processes as the initiation of the criminal proceedings or (in many situations) the necessity to continue the proceedings, for example, in case of reconciliation.

In reference to the influence of the offence victim's on the existence of the proceedings at the time of their initiation, it is important to bear in mind the basic idea of the criminal proceedings - they are conducted in the interests of all members of the public for the offence that has been detrimental to the entire society. The acknowledgement of this fact is closely connected to the mandatory principle of the criminal proceedings, which is included into Article 6 of CPL. However, the mandatory principle of the criminal proceedings is not without any restrictions because in many cases the position of the officials who conduct the criminal proceedings is not the determining one when the criminal proceedings are initiated; instead, the decisive role belongs to the victim of the offence [9]. 
According to Section II of Article 96 of CPL, the one who promotes the proceedings promptly informs the person about his/her rights to be recognized as a victim in the criminal proceedings, yet Section III of the same article provides that a person can be recognized as a victim only under the condition of this person's or his/her legal representative's written consent. The person who does not wish to be recognized as a victim acquires the status of a witness, which is why CPL does not contain a mandatory requirement that a person who has suffered in an offence must be recognized as a victim in the criminal proceedings [10].

Section II of Article 370 of CPL provides that the criminal proceedings can be initiated if the information contains information on the occurrence of a possible offence and it can be verified only using the means and methods of the criminal proceedings.

This means that the institution that passes the decision to initiate the criminal proceedings in the beginning must review each received application or information in order to be able to determine if this information points to the possibility of the occurrence of the offence, and no any other features could be identifiable, for example, the features of violation of the civil rights, and that additionally it is important to determine the grounds for existence for the initiation of the criminal proceedings in accord with Article 370 of CPL.

In the initial stage of the criminal proceedings the official who must ensure the observance of the mandatory nature of the criminal proceedings should implement specific filtering functions identifying the offences which require the initiation of the criminal proceedings and those which do not. In order to ensure the effective application of the CPL norms and the fair regulation of the criminal legal relation, this official, initiating the criminal proceedings, should be able to identify features of the offence [11].

Having determined the necessity to initiate the criminal proceedings, the institution responsible for the progress of the criminal proceedings must immediately decide on the issue of competence in initiating the criminal proceedings.

It must acknowledge that Article 6 of CPL that provides an indication to the "officials who have the power of attorney to conduct the proceedings" does not have a precise definition of such an official as not all officials, conducting the criminal proceedings, have the right to initiate and complete the criminal proceedings. Section II of Article 26 of CPL provides that the power of attorney in the specific criminal proceedings is obtained by:

1) the person directing the proceedings;

2) a member of the investigative group;

3) the supervising public prosecutor;

4) an official authorised to perform criminal proceedings who executes the task of the person directing the proceedings, a member of the investigative group, or the court to conduct procedural actions;

5) an expert from an expert-examination institution;

6) an expert who does not work at an expert-examination institution, if the person directing the criminal proceedings has assigned him or her to perform an expertexamination;

7) an auditor on the assignment of the person directing the proceedings;

8) the direct supervisor of an investigator;

9) the senior public prosecutor;

10) the investigating judge;

11) the counsel for the prosecution.

However, having conducted the systematic analysis of the CPL norms, it is possible to conclude that only the investigator, the investigator's superior and the prosecutor, not all officials that are mentioned in Article 25 of CPL, have the legal rights to pass the decision on the initiation of the criminal proceedings. 
For example, Section V of Article 371 of CPL states that the judge or the court forward the application, materials or information that has been obtained during the hearing, without the judgement, to the prosecution institution or in cases determined in the law to the prosecution authorities. Therefore, this paper concludes that the judge or the court does not pass the decision on the initiation of the criminal proceedings, however, during court hearing, having identified the likelihood of the occurrence of the offence, the judge or the court makes the decision to forward the case to the competent authorities for the final decision.

This is the way how the principle of separation of the procedural functions is ensured, which prohibits the court to accept the prosecution function [12].

Section I of Article 29 of CPL provides that the duties of the investigator include the obligation to review information that points to the commitment of a possible offence and to initiate the criminal proceedings as soon as the reason and grounds for doing so, which are outlined in CPL, are identified, or else to reject the initiation of the criminal proceedings.

Section I of Article 371 of CPL determines that the direct supervisor of the investigator or the investigator have the responsibility to conduct the criminal proceedings only within the scope of their competences and in accord with the reasons mentioned in Article 369. In turn, Article 31 of CPL, which describes the competence of the direct supervisor of the investigator, does not mention that fact that the duties of the direct superior of the investigator include the rights to make the decision on the initiation of the criminal proceedings. Therefore, it would be necessary to expand Section II of Article 31 of CPL by introducing a new point: "The duties of the direct superior of the investigator include passing the decision on the initiation of the criminal proceedings in connection to any reason mentioned in Article 369 of this law".

In pertinence to the competence of the prosecutor, it might be possible to distinguish a few situations:

1) Section II of Article 371 of CPL determines that the prosecutor can forward materials for the review to the prosecution institution, or

2) can initiate the criminal proceedings within the scope of own competence in connection to any reason mentioned in CPL. Having initiated the criminal proceedings, the prosecutor usually forwards the criminal case to the investigator for conducting investigation.

3) However, Section II of Article 36 of CPL provides that in the cases provided by the law the prosecutor decides on the initiation of the criminal proceedings and the prosecutor himself/herself conducts investigation. The exceptional case would be the situation when at the stage of investigation the Prosecutor General, the Criminal Legal Department of Prosecution General or the Supervising Prosecutor of the District Court can appoint the prosecutor as the promoter of the proceedings.

In this case, the prosecutor, as a promoter of the case, similarly to the investigator, organizes the direction of the criminal proceedings and at the investigation stage uses the power of the attorney given by the state by himself/herself or engaging other officials or else demands that each person complete and observe the duties outlined in the order of the criminal proceedings; furthermore, the prosecutor in the criminal proceedings ensures for all parties involved the opportunity to exercise the rights outlined in the law [13].

As it is provided by CPL, the supervision aim of the supervising prosecutor is to ensure the target-oriented investigation, not to allow unfair intrusion into the person's life or faltering, not to allow procedural violations that threaten the progress of the criminal proceedings. Importantly, the supervising tools provided by CPL to the prosecutor include giving instructions by the prosecutor, engagement in conducting of procedural activities, the rights to study the criminal proceedings materials at any time, the rights to participate in 
the session in which the investigating judge decides on issuing the permit to use coercive instruments un to conduct activities of special investigation, the rights to annul the decisions of the promoter of the process and of the member of the investigation group etc. [14].

Yet another aspect that should be reviewed in the context of the basic mandatory principle is the duty not only to initiate the criminal proceedings, but also "to take the case to the stage of the fair regulation of the criminal legal relation provided in the Criminal Law".

Hence, some sort of contradiction emerges between Article 6 of CPL, which in relation to the initiation principle of the criminal proceedings has the ensured mandatory principle, and Section II of Article 373 of CPL, which provides the so-called expediency principle. According to this article, an investigator, with the consent of a public prosecutor, may refuse the initiation of criminal proceedings, if a criminal offence has been committed that has the features of a criminal offence, but which has not caused such harm that would warrant the application of a criminal punishment.

CPL provides for the opportunity to reject the initiation of the criminal proceedings or stop the already initiated criminal proceedings based on the grounds that the committed offence, which has the features of the criminal offence and which has not caused such damage as to demand the criminal penalty (including the so-called "minor damage" cases). This allows the investigation institutions to "relieve" from conducting criminal proceedings in cases when the incurred damage is evidently "of no significance". In accord with CPL, this instrument, used by the promoter of the process, can be utilized with the consent of the supervising prosecutor, which points to the significant role of the prosecutor in this matter. Although this instruments is provided in the law in order not to handle criminal proceedings cases that have not caused such damage as to demand the application of the criminal penalty, in reality this norm is not sufficiently used because the unified understanding and interpretation regarding the cases which would be considered as "minor damage" cases have not yet been reached.

In accord with the assessment of the State Control of the Republic of Latvia, for legal clarity and certainty purposes it would be necessary to determine additional criteria for the application of this norm. Therefore, reaching a consensus on when not to apply the initiation of the criminal proceedings because the given cases could be considered as cases of "minor damage", could be successfully applied in real life as an instrument which provides for the opportunity to redirect freed resources to the investigation of more important cases [15].

In addition, it would be necessary to conduct the amendments of the legal regulation of the basic mandatory principle by providing for exceptional cases when the criminal proceedings might not be initiated.

\section{Results}

The mandatory principle of the criminal proceedings is one of fair components of the criminal proceedings and it must be considered by the official who has the power of the attorney (the promoter of the process), when passing the decision on initiation of the criminal proceedings.

The following findings were discovered:

1) The Criminal Procedure Law gives the authority to perform criminal proceedings to more than ten officials, however only a few of them can initiate in criminal proceedings. In addition, there are certain contradictions in the legal framework, for example, regarding the competence of the direct supervisor of an investigator;

2) initiating criminal proceedings must always remember that there are cases where criminal proceedings are initiated only if a request has been received from the person to whom harm has been inflicted; 
3) contrary to the principle, there are exceptions to the law when it is possible to refuse to initiate criminal proceedings;

4) only when the person who committed the criminal offence is determined, it is possible to lead such proceedings to the fair regulation of criminal legal relations provided for in The Criminal Law.

\section{Conclusions}

1) It is necessary to amend the Criminal Procedure Law by resolving contradictions in the legal regulations of the direct supervisor of an investigator.

2) What could be discussed, is the purpose of the principle of mandatory nature of criminal proceedings. How to achieve a fair regulation of criminal legal relations in all cases when criminal proceedings are initiated?

3) Article 6 of the Criminal Procedure Law needs to be defined that there are exceptions to the mandatory nature of criminal proceedings.

\section{References}

[1] Latvijas tiesību sistēma / Aut. kol. A. Endziņš, J. Načisčonis, S. Kaija u.c. Rīga, SIA Turība Biznesa augstskola, 2017, 25 lpp

[2] Meikališa, Ā., Strada K. Kriminālprocesuālo terminu skaidrojošā vārdnīca. Rīga, RaKa, 2000, 123 1pp

[3] Kriminālprocesa likums: LR likums. Latvijas Vēstnesis 74 (3232), 21.04.2005, 6.pants

[4] Meikališa, Ā., Strada-Rozenberga, K. Taisn̄̄gums kriminālprocesā // Jurista vārds Nr. 48 (695)

[5] Meikališa, Ā., Strada-Rozenberga, K., Kriminālprocess raksti 2005-2010. Rīga, Latvijas Vēstnesis, 2010, 65-66 lpp

[6] Strada-Rozenberga, K. Publisko un privāto interešu kolīzija kriminālprocesā. Politika un tiesības. Tiesību un juridiskās prakses ilgtspējīga attīstība.// Available: https://www.lu.lv/fileadmin/user_upload/lu_portal/apgads/PDF/ Juristu-konf_PLZK_2012_.pdf

[7] Meikališa, Ā., Strada-Rozenberga K. Pārmaiņu laiks kriminālprocesā // Jurista vārds Nr. 11 (414)

[8] Kriminālprocesa likums. LV likums. Latvijas Vēstnesis:11.05.2005., 369.pants

[9] Strada-Rozenberga, K. Cietušais un tā tiesības kriminālprocesā // Jurista vārds Nr. 42 (547)

[10] Latvijas Republikas Augstākās tiesas Senāta Krimināllietu departamenta 2013. gada 20.marta lēmums lietā SKK -31/2013 (Krimināllieta Nr. 11840003309)// Available: http://at.gov.lv/downloadlawfile/3792

[11] Baumanis, J. Publisko apsūdzību kriminālprocesa uzsākšanas teorētiskie praktiskās problēmas // Administratīvā un kriminālā justīcija 4/2007 (Nr.4/41), 2007, 89. lpp

[12] Kaija, S. Issues in Separation of Criminal Procedural Functions. $6^{\text {th }}$ International Interdisciplinary Scientific Conference SOCIETY. HEALTH. WELFARE. SHS Web Conf. Volume 40, 2018 // Available: https://www.shs-conferences.org/ articles/shsconf/abs/2018/01/shsconf_shw2018_01010/shsconf_ shw2018_01010.html

[13] Rokasgrāmata prokuroriem. Kūtra, G. zinātniskajā redakcijāa, Rīga, Tiesu nama aǵentūra, 2010, 9 1pp 
[14] Vai pirmstiesas izmeklēšana Valsts policijā ir efektīva? Latvijas Republikas Valsts kontrole// Available: http://www.lrvk.gov.lv/uploads//revizijuzinojumi/2016/2.4.1-6_2016/rz_vp_20.09.2017_bez-ip.pdf

[15] Vai pirmstiesas izmeklēšana Valsts policijā ir efektīva? Latvijas Republikas Valsts kontrole// Available: http://www.lrvk.gov.lv/uploads//revizijuzinojumi/2016/2.4.1-6_2016/rz_vp_20.09.2017_bez-ip.pdf 